\title{
17 Alfa Hidroksilaz/17,20 Liyaz Eksikliği olan Hastada Anestezi Yönetimi
}

\author{
Anesthesia Management in a Patient with 17 Alpha Hydroxylase/17,20 Lyase Deficiency
}

Metin Alkan, Naciye Türk Özterlemez, Çağrı Özdemir, Ömer Kurtipek, Mustafa Arslan

Gazi Üniversitesi Tıp Fakültesi Anesteziyoloji ve Reanimasyon Anabilim Dalı, Besevler, Ankara, Türkiye

\section{ÖZET}

Konjenital adrenal hiperplazi (KAH), adrenal kortekste kortizol ve seks steroidlerin biyosentezinde yer alan enzimlerden herhangi birinin kalıtsal kusurundan kaynaklanan otozomal resesif bozukluktur. En sık 21-hidroksilaz eksikliği (\% 90-95) görülmesine rağmen $17 \alpha$-hidroksilaz/17,20 liyaz eksikliği en az görülen tipidir (<\% 1 ). Bu enzim eksiklikleri sonucunda kortizol üretiminde yetersizlik ve buna bağlı olarak da kortikotropin serbestleștirici hormon (CRH) ve aderenokortikotropin hormon ( $\mathrm{ACTH}$ ) üretiminde artış olmaktadır. Oluşan bu hormonal üretim bozukluğunun tedavisinde glukokortikoidler ve seks steroidleri uzun süreli kullanılmaktadır. Dolayısıyla anestezi yönetimi bu hasta grubunda özellik arz etmektedir. Biz bu vakada 17 $\alpha$-hidroksilaz/17,20 liyaz eksikliği olan ve bu nedenle uzun süreli steroid kullanım öyküsü mevcut 38 yaşında kadın hastaya guatr nedeniyle planlanan tiroidektomi operasyonu için genel anestezi yönetimini sunmayı amaçladık.

Anahtar Sözcükler: 17 a Hidroksilaz/17,20 Liyaz eksikliği, miyopati, genel anestezi

Geliş Tarihi: 27.12.2017

\section{ABSTRACT}

Congenital adrenal hyperplasia (CAH) is a an autosomal recessive disorder resulting from a defect in any of several enzymes involved in biosenthesis of cortisol and sex steroids in adrenal cortex. 21-hydroxylase deficiency (90-95\%) is the most common form and $17 \alpha$-hydroxylase / 17,20 lyase deficiency is the least common $(<1 \%)$. These enzyme deficiencies result in inadequate cortisol production and consequently increased production of corticotropin-releasing hormone (CRH) and adrenocorticotropin hormone (ACTH). Glucocorticoids and sex steroids are used for this hormonal production disorder as a long time treatment. Therefore, anesthesia management is characteristic in this patient group. We aimed to present general anesthesia management for a thyroidectomy operation planned for a 38-year-old female patient with $17 \alpha$ hydroxylase / 17,20 lyase deficiency with a history of steroid use.

Key Words:17 $\alpha$-hydroxylase/17,20-lyase deficiency, myopathy, general anesthesia

Received: 12.27 .2017

Accepted: 01.25 .2018

Biz bu vaka sunumunda $17 \alpha$-hidroksilaz 17,20-liyaz eksikliği olan ve uzun süredir steroid kullanımı olan 38 yaşındaki kadın hastanın tiroidektomi cerrahisinde uygulanan genel anestezi yönetimini tartışmayı amaçladık. ve kortizol öncülü 17- $\alpha$ hidroksi progesterona (17-OHP) dönüşümünde kusur vardır. P450c17 enzim eksikliğinde kortizol, androjen ve östrojen üretimi yapılamaz ve feedback mekanizması ile adrenokortikotropik hormon (ACTH) üretimi kortizol üretimini sağlamak için artar ve bu durum adrenal bezde hiperplaziye neden olur (1). ACTH üretimindeki artış güçlü mineralokortikoid olan 11 deoksikortikosteron (DOC) ve kortikosteron üretimini uyarır. Mineralokortikoid üretiminin artışı ise total vücut sıvısında artışa, hipertansiyona ve hipokalemiye neden olur (1). Seks steroidlerindeki yetersizlik bu enzim eksikliğine sahip erkek bireylerde belirsiz ya da dişi dış genital görünüme neden olur. Dişi bireylerde ise doğumda normal dişi dış genital görünüm olmasına rağmen gecikmiş puberte ile kendini gösterir (2).

$17 \alpha$-hidroksilaz 17,20 liyaz enzim eksikliğinin tedavisinde temel hedef yetersiz miktarda bulunan adrenal steroidlerin yerine konulmasıdır. Uzun süreli kullanılan bu steroidlerin birçok yan etkisi mevcuttur. Miyopati glukokortikoid tedavisinin bilinen bir yan etkisidir. İlaca bağlı miyopati en sık glukokortikoid kullanımından kaynaklanır. Glukokortikoid ilişkili miyopati ağrısız kas güçsüzlüğü, yorgunluk ve atrofi ile karakterizedir (3). Miyopati, glukokortikoidlerin protein sentezini azaltması ve protein yıkımını artırması ile ortaya çıkar. Steroid ilişkili miyopatinin başlangıcı genellikle sinsidir ve spesifik laboratuvar bulguları mevcut değildir. Yapılan kas biyopsisinde non-spesifik tip 2 fiber atrofisi saptanmıştır. Patofizyolojisi tam aydınlatılamamış olsa da son çalışmalar glutamin sentetazın steroid ilişkili miyopatide önemli rol aldığı söylenmektedir (4).

\section{OLGU SUNUMU}

Multinodüler guatr nedeniyle hastanemiz endokrinoloji ve metabolizma kliniğinde takipli olan 38 yaşında 80.7 kg ağırlığında $171 \mathrm{~cm}$ boyunda kadın hasta genel cerrahi bölümü tarafından tiroidektomi amacıyla yatırıldı. Hastanın özgeçmiş sorgusunda KAH tanısı olduğu öğrenildi. Hasta thyromazol $5 \mathrm{mg}$ /günde bir defa, dekort $0.25 \mathrm{mg} /$ günde bir defa, seroquel $25 \mathrm{mg}$ /günde

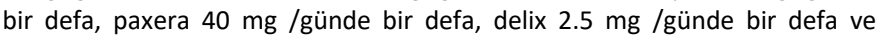
östrojen+progesteron tedavilerini almaktaydı. Özgeçmişinde $\mathrm{KAH}$ dışında kronik depresyon hastalığının da olduğunu ve bu nedenle hastaya dış merkezde 7 kez elektrokonvülsif tedavi (EKT) yapıldığı öğrenildi. Preoperatif dönemde yapılan laboratuvar testlerinde tam kan, karaciğer ve böbrek fonksiyon testleri normal sınırlarda tespit edildi. Tiroit fonksiyon testleri tedavi altında normal olarak tespit edildi. Elektrokardiyografi de anormal bulgu saptanmadı ve posterior-anterior akciğer grafisinde parankim doğal olarak değerlendirildi. Preoperatif değerlendirmede kas güçsüzlüğü saptanan hasta nöroloji kliniği tarafından değerlendirildi. Bu amaçla yapılan elektromiyografi (EMG) tetkikinde hastanın miyopatisi olduğu saptandı. Miyopatinin kronik steroid kullanımına bağı ortaya çıktığı düşünüldü. Yapılan tetkikleri ile birlikte değerlendirilen hastaya operasyon kararı alınarak olası riskler hakkında bilgilendirilme yapılarak ameliyat için yazılı onamı alındı. 
Hastaya kronik steroid kullanımı nedeniyle addison protokolü uygulandı (operasyon günü metilprednizolon $10 \mathrm{mg} /$ günde 4 defa, postoperatif 1 . gün $10 \mathrm{mg} /$ günde $3 \mathrm{defa}$, postoperatif 2 . gün $10 \mathrm{mg} /$ günde $2 \mathrm{defa}$ ). Bu protokolle birlikte steroidi uygulamasının olası gastrointestinal yen etkileri nedeniyle ranitidin $25 \mathrm{mg}$ intravenöz (i.v.) uygulandı. Kronik steroid kullanan hastada olası immün baskılanma ve enfeksiyona yatkınlık göz önüne alınarak sefazolin i.v. $1 \mathrm{gr}$ dozda cerrahi cilt kesisi öncesinde uygulandı. Operasyon odasına alınan hastaya standart monitörizasyon (EKG, noninvaziv kan basıncı monitörizasyonu, pulseoksimetre ile $\mathrm{SpO}_{2}$ ) yanı sıra " train-of-four (TOF)" cihazı (TOF Watch SX, Organon Teknika, İrlanda) elektrotlarının yerleştirileceği cilt bölgesi alkol ile silindikten sonra, önkol ulnar sinir trasesine iki adet elektrot yerleştirildi ve TOF monitörizasyonu yapıldı (Resim 1). Anestezi indüksiyonundan sonra akseleromiyografik TOF stimülasyonu ( $50 \mathrm{~mA}^{\prime}$ lik akım, $2 \mathrm{~Hz}$ frekans ve 0,2 milisaniye her bir uyarı süresi) ile ulnar sinir uyarılarak adductor pollicis kasının kontraksiyonu kontrol edildi. Preoperatif mallampati skoru 2 saptanan hastada zor entübasyon beklenmedi. Nöromusküler monitörizasyonu (TOF) altında remifentanil $(1 \mu \mathrm{g} / \mathrm{kg} / \mathrm{dk}$, yükleme dozu) ve propofol $(2 \mathrm{mg} / \mathrm{kg})$ i.v. yoldan verildi. Hastanın TOF değeri ölçülerek rokuronyum $(0.375 \mathrm{mg} / \mathrm{kg})$ uygulandı. TOF değeri 1 olan hasta 7.5 numara kaflı endotrakeal tüp ile başarılı bir şekilde entübe edildi. Anestezi idamesi desfluran (MAK 1), remifentanil $\left(0.2 \mu \mathrm{g} / \mathrm{kg} / \mathrm{dk}\right.$ infüzyon) ve $\mathrm{O}_{2} /$ hava (\% 50) ile sağlandı. Operasyon boyunca TOF ile takip edildi ve herhangi bir ek kas gevşetici uygulanmadı. Operasyon bitiminde TOF değeri baz alınarak sugammadeks $(2 \mathrm{mg} / \mathrm{kg})$ uygulandı. TOF kontrolü yapılan hasta ekstübe edilerek ayılma odasına alındı. Ayılma odasında herhangi bir problem yaşanmayan hasta takip amacıyla servisteki yatağına gönderildi. Perioperatif dönemde adrenal supresyona bağlı gelişen herhangi bir bulgu izlenmedi(Resim 1).

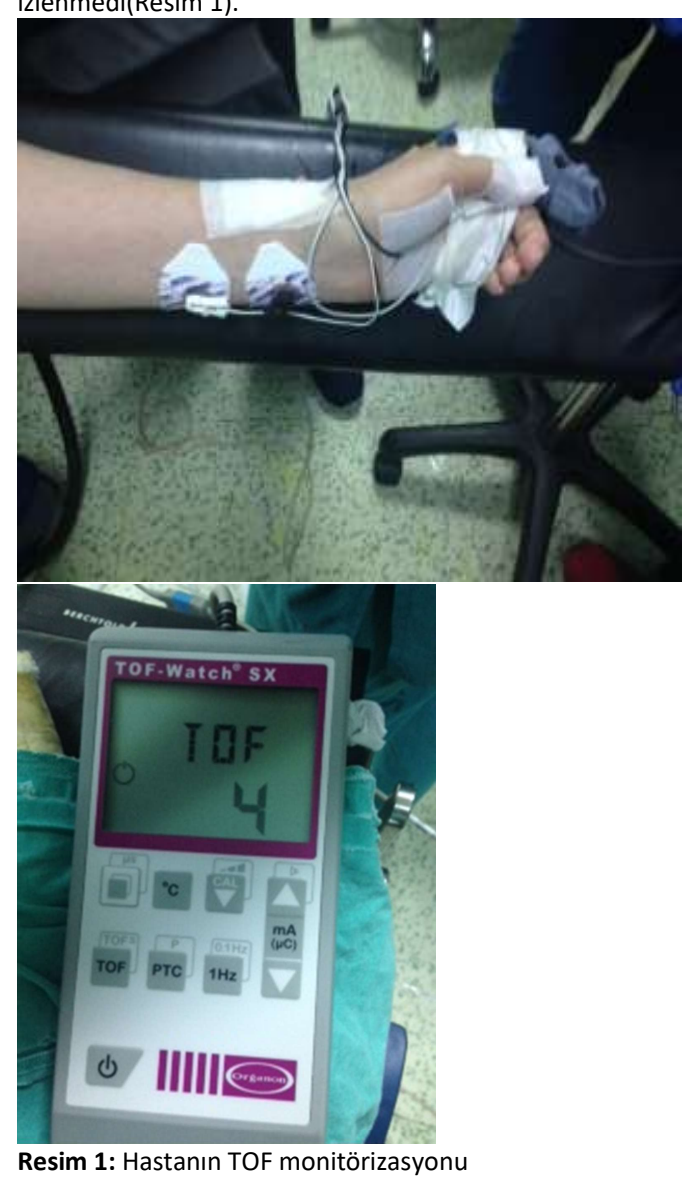

Resim 1: Hastanın TOF monitörizasyonu

\section{TARTIŞMA}

Biglieri ve ark. (5) tarafından 1966 yılında hipertansiyon, seksüel infantilizm ve primer amenoresi olan 35 yaşında kadın bir hastada tanımlanan $17 \alpha$-hidroksilaz eksikliği nadir görülen (1/50000-100000) bir KAH tipi olup; tüm KAH olgularının yaklaşık \% $1^{\prime}$ ini oluşturmaktadır. Konjenital adrenal hiperplazide en sık 21-hidroksilaz ve $11 \beta$-hidroksilaz eksikliği görülmektedir. Bu enzim eksikliklerin ortak özelliği kadın hastalarda hiperandrojenizm ve heteroseksüel erken puberte ile karakterizedir. $17 \alpha$-hidroksilaz/17,20-liyaz eksikliğinde seksüel infantilizm görülür. Ancak diğer enzim eksikliklerinden farklı olarak hiperandrojenizm bu hastalarda görülmemektedir (6).

Sağlıklı bireylerde azalmış steroid sentezi sonrasında ACTH üretimi steroid sentezini normal düzeye döndürmek için artar. Fakat KAH hastalarında steroid sentezinin yetersiz olması ACTH üretimini artırarak mineralokortikoid sentezinin aşırı olmasına ve adrenal hiperplaziye neden olmaktadır.
Mineralokortikoidlerin aşırı üretimi ise sodyum ve su tutulmasına, potasyum ve hidrojen atılmasına, hipokalemik alkolozis ve hipertansiyon ile sonuçlanmaktadır $(6,7) .17 \alpha$-hidroksilaz/17,20-liyaz enzimi adrenal bezde ve gonadlarda bulunmakta, fetal hayatta ve pubertede seksüel gelişimi sağlamaktadır. Bu nedenle $17 \alpha$-hidroksilaz/17,20-liyaz enzim eksikliğinde etkilenen erkek bireylerde ambigus genitalya ya da dişi dış görünüm olabilmektedir. Etkilenen dişi bireylerde ise normal dişi dış genital olmasına rağmen seksüel yapılar tam gelişmemiş olup, primer amenore görülmektedir $(5,7)$.

Hastalığın tanısı klinik, biyokimyasal ve moleküler tetkikler sonucunda konulmaktadır. Tedavisinde ise eksik olan glukokortikoidleri ve seks steroidlerinin replasmanı yer almaktadır. Hormon replasmanı tedavisi sonucunda sıvı elektrolit dengesi sağlanmakta ve hipertansiyon giderilmektedir. Seks steroidlerinin replasmanı adölesan dönemde sekonder seks karakterlerinin gelişimini sağlamak için kullanılmaktadır (2). Bizim hastamız da östrojen+progesteron tedavisini adölesan döneminden itibaren düzenli olarak kullanmaktaydı. Hastalığın tedavisinde kullanılan steroidlerin uzun süreli kullanımı miyopati dahil olmak üzere birçok yan etkisi mevcuttur. Miyopati glukokortikoid tedavisinde protein sentezinin azalması ve yıkımının artmasına neden olan protein katabolizması ile ilişkili olduğu söylenmektedir (3). Dolayısıyla bu tür uzun süreli steroid tedavisi alan hastaların preoperatif dönemde iyi değerlendirilip, miyopati yönünden araştırılması gerekir. Miyopatisi olan hastaların preoperatif dönemde değerlendirilip solunum yolu problemleri açısından dikkatli muayenelerinin yapılması gerektiği kanaatindeyiz. Hastaların intraoperatif dönemde nöromüsküler blokaj amaçı ı kullanılan kas gevşetici ajanların mümkün olduğunca düşük dozlarda kullanılması ve mümkünse nöromüsküler monitörizasyon yapılarak ek dozların yapılması gerektiğini düşünüyoruz. Ayrıca bu hasta grubunda kısa ve orta etki süreli kas gevşeticilerin tercih edilmesi gerekir. Biz de sunduğumuz bu vakada rokuronyum gibi orta etki süreli bir ajanı düşük dozda kullandık ve nöromüsküler monitörizasyon sağlayarak ek doz kullanma intiyacı duymadık.

Bizim hastada da olduğu gibi ekzojen steroid tedavisi gerektiren çok sayıda klinik durum olmasına rağmen en sıklıkla romatoid artrit, crohn hastalı̆ı ve bronşiyal astım tedavisinde uzun süreli steroid tedavisi gerekebilmektedir. Bu tedaviler sonucunda da sıklıkla hipotalamo - piüiter- adrenal aks baskılanması görülebilmektedir. Dışarıdan alınan her steroid vücutta oluşan endojen kortizol düzeyini baskılamaktadır. Anestezi indüksiyonunu takiben plazma kortizol düzeyi, cerrahi süresince ve postoperatif dönemde 2-10 kat artabilmektedir. Maksimum ACTH ve kortizol düzeyi anesteziden derlenme ve ekstübasyon sonrasında görülmektedir. Ancak kortikosteroid tedavisi alan hastalar perioperatif dönemde cerrahi strese uygun endojen kortizol sentezi ile yanıt veremeyebilirler. Vücuttaki kortizol epinefrin, norepinefrinin etkinliği için, homeostazisin sürdürülmesi ve şokun önlenmesi için hayati önem taşımaktadır. Bundan dolayı anestezi sırasında steroid replasmanı için dikkatli plan yapılması gerekir $(8,9)$. Biz de hastamızın uzun süreli steroid tedavisi altında almasından dolayı peroperatif dönemde kliniğimizin addison protokolü çerçevesinde steroid replasmanı uyguladık.

Sonuç olarak; konjenital adrenal hiperplazi tanılı hastalarda uzun süreli steroid tedavisine bağlı gelişen miyopati nedeniyle bu hastalarda uygun nöromüsküler ajanın seçilmesi ve nöromüsküler monitörizasyon sağlanarak dozunun düşük tutulması gerektiğini düşünüyoruz. Ayrıca peroperatif dönemde uygun steroid replasmanının yapılması gerektiği kanaatindeyiz.

\section{Çıkar Çatışması}

Yazarlar herhangi bir çıkar çatışması bildirmemişlerdir.

\section{KAYNAKLAR}

1. Auchus RJ. The genetics, pathophysiology, and management of human deficiencies of P450c17. Endocrinol Metab Clin North Am 2001;30:101-19.

2. Miller WL. Androgen synthesis in adrenarche. Rev Endocr Metab Disord 2009;10:3-17.

3. Friedrich $\mathrm{O}$, Reid MB, Van den Berghe $\mathrm{G}$, Vanhorebeek I, Hermans $\mathrm{G}$, Rich MM, et al The Sick and the Weak: Neuropathies/Myopathies in the Critically III. Physiol Rev. 2015;95:1025-109.

4. Kanda F, Okuda S, Matsushita T, Takatani K, Kimura KI, Chihara K. Steroid myopathy: pathogenesis and effects of growth hormone and insulin-like growth factor-I administration. Horm Res 2001;56 Suppl1:24-8.

5. Biglieri EG, Herron MA, Brust N. 17-hydroxylation deficiency in man. J Clin Invest 1966; 45: 1946-1954.

6. Kim SM, Rhee JH. A case of 17 alpha-hydroxylase deficiency, Clin Exp Reprod Med 2015 Jun;42:72-6.

7. Xu S, Hu S, Yu X, Zhang M, Yang Y. 17 $\alpha$-hydroxylase/17,20-lyase deficiency in congenital adrenal hyperplasia: A case report. Mol Med Rep 2017;15:339-344.

8. Wakim JH, Sledge KC. Anesthetic implications for patients receiving exogenous corticosteroids. AANA J 2006;74:133-9.

9. Shaikh S, Verma H, Yadav N, Jauhari M, Bullangowda J. Applications of Steroid in Clinical Practice: A Review. International Scholarly Research Network ISRN Anesthesiology Volume 2012, Article ID 985495, 11 pages doi:10.5402/2012/985495. 